\title{
Pedicellariae of the crown-of-thorns sea star Acanthaster planci are not an effective defence against fouling
}

\author{
Jana Guenther*, Kirsten Heimann, Rocky de Nys \\ School of Marine and Tropical Biology, James Cook University, Angus Smith Drive, Townsville, Queensland 4811, Australia
}

\begin{abstract}
This study focused on the speculative role of the pedicellariae of the sea star Acanthaster planci in fouling control, because quantitative measurements showed that this species is free of any macro-fouling organisms. The morphology and distribution of its pedicellariae were measured to determine if larvae or propagules of fouling organisms could settle between pedicellariae without being in their physical range. The elementary and straight pedicellariae of A. planci had a mean length of $0.7 \mathrm{~mm}$ and were spaced at a mean distance of $2.6 \mathrm{~mm}$. The total number of pedicellariae was proportional to the estimated surface area of $A$. planci. To determine how pedicellariae respond to tactile stimulation, pedicellariae were stimulated by touching either inner, outer or basal sites of pedicellariae with a hypodermic needle. Pedicellariae closed rapidly on touch and closed for significantly longer when touched on their inner sites $(8.9 \mathrm{~s})$ than outer $(6.7 \mathrm{~s})$ and basal $(7.9 \mathrm{~s})$ sites. Settling larvae were simulated by dropping silica beads (size: 50.2, 181.5, 255.7 and $510.7 \mu \mathrm{m}$; density: $2.5 \mathrm{~g}$ $\mathrm{ml}^{-1}$ ) and zirconium/silica beads (size: 191.2 and $507.6 \mu \mathrm{m}$; density: $3.7 \mathrm{~g} \mathrm{ml}^{-1}$ ) over the pedicellariae. The percentage of responding pedicellariae increased proportionally with increasing size of the silica beads. The percentage also increased when zirconium/silica beads of similar size but higher density were used, demonstrating that the mass, not size, of the beads was the main driving factor for the closure of pedicellariae. Pedicellariae were also stimulated by placing larvae of the bryozoan Bugula neritina $(250 \mu \mathrm{m})$ and fragments of the alga Chrysocystis fragilis (150 to $1000 \mu \mathrm{m})$ over the pedicellariae. However, the response of the pedicellariae to the larvae of $B$. neritina was consistently low and none of the pedicellariae responded to the fragments of $C$. fragilis. These results demonstrated that for A. planci, the pedicellariae offer little or no defence against fouling.
\end{abstract}

KEY WORDS: Elementary pedicellariae $\cdot$ Acanthaster planci $\cdot$ Bugula neritina $\cdot$ Chrysocystis fragilis Tactile stimulation $\cdot$ Antifouling defence

Resale or republication not permitted without written consent of the publisher

\section{INTRODUCTION}

Pedicellariae are forcep- or pincer-like appendages made of calcareous ossicles and found in 2 echinoderm classes, Echinoidea and Asteroidea (Chia \& Amerongen 1975, Campbell \& Rainbow 1977). Echinoderm pedicellariae have reported functions in capturing particles and mobile prey, such as small crustaceans or fish (Robilliard 1971, Campbell 1973, 1974, Chia \& Amerongen 1975, Hendler \& Franz 1982, Dearborn et al. 1991, Emson \& Young 1994, Lauerman 1998), and in deterring predators or competing sea stars (Jensen 1966, Lubchenco Menge \& Menge 1974, van Veldhuizen \& Oakes 1981). Furthermore, echinoid pedicellariae are proposed to protect the surface from settling fouling organisms. The only study on the protective role of echinoid pedicellariae showed that mobile pedicellariae and spines of the echinoid Echinus esculentus prevented the settlement of cyprid larvae of the barnacle Balanus balanoides as a defence against fouling (Campbell \& Rainbow 1977). Although echinoid and asteroid pedicellariae do not share common traits 
(Jangoux \& Lambert 1988), many articles and books suggest, or even state, that asteroid pedicellariae also prevent the settlement of fouling organisms (e.g. Nichols 1966, Ruppert \& Barnes 1994) as well as foreign materials and organisms (Campbell 1971, Lambert et al. 1984, Roberts \& Campbell 1988). However, the structure of asteroid pedicellariae combined with their proposed role in keeping the surface free of any macro-fouling organisms has not been rigorously examined and remains speculative.

The crown-of-thorns sea star Acanthaster planci Linneaus (Asteroidea: Valvatida: Acanthasteridae; Rowe \& Gates 1995) is widely distributed in IndoPacific coral reef communities, where it mainly feeds on staghorn and plate corals (Moran 1988). This species has large pedicellariae, but their morphology, distribution and role require more thorough investigations. Early studies described that the pedicellariae of A. planci consisted of 2 elongate valves that were variable in size and shape, and that they were abundant on the aboral surface (Campbell 1971, Caso 1974, Blake 1979). Campbell (1971) also showed that the pedicellariae of $A$. planci responded to tactile stimulation, such as a touch with a bristle or small spine, and movements of the commensal shrimp Periclimenes soror. However, no further studies on the functional role of the pedicellariae of $A$. planci have been conducted. The abundance of $A$. planci and its occurrence in the tropics, where fouling pressure is high, make it an ideal organism with which to rigorously investigate the role of pedicellariae as a defence against fouling in sea stars.

The aims of this study were to identify the role of the pedicellariae of Acanthaster planci in fouling control through quantifying (1) the morphology, distribution and abundance of the pedicellariae on the aboral surface of A. planci and (2) their response to tactile stimulation with a hypodermic needle, silica and zirconium/silica beads and 2 ecologically relevant fouling species, the bryozoan Bugula neritina and the chrysophyte alga Chrysocystis fragilis.

\section{MATERIALS AND METHODS}

Collection and culture of Acanthaster planci and macro-fouling organisms. Live specimens of Acanthaster planci were collected from the northern part of the Great Barrier Reef (GBR), Queensland, Australia: Little Broadhurst Reef $\left(18^{\circ} 58^{\prime} \mathrm{S}, 147^{\circ} 41^{\prime} \mathrm{E}\right)$ in August 2004 ( $\mathrm{n}=10)$, Mid Reef $\left(19^{\circ} 04^{\prime} \mathrm{S}, 148^{\circ} 05^{\prime} \mathrm{E}\right)$ in May 2005 ( $\mathrm{n}=13)$, Davies Reef $\left(18^{\circ} 50^{\prime} \mathrm{S}, 147^{\circ} 38^{\prime} \mathrm{E}\right)$ in November $2005(\mathrm{n}=7)$ and Bait Reef $\left(19^{\circ} 48^{\prime} \mathrm{S}\right.$, $\left.149^{\circ} 04^{\prime} \mathrm{E}\right)$ in February $2006(\mathrm{n}=11)$. Following collection, they were visually inspected for any macro-foul- ing organisms and their size (R: major radius measured from centre to arm tip, $\mathrm{r}$ : minor radius measured from centre to interradial margin) was measured to the nearest mm using a vernier caliper. Specimens were kept temporarily in an outdoor recirculating tank $\left(26^{\circ} \mathrm{C}\right.$ temperature, $35 \mathrm{ppt}$ salinity) at the Marine and Aquaculture Research Facilities Unit at James Cook University. Several colonies of the bryozoan Bugula neritina were collected from pier pilings in Townsville $\left(19.26^{\circ} \mathrm{S}, 146.80^{\circ} \mathrm{E}\right)$ and kept in constant darkness for $2 \mathrm{~d}$ in a recirculating tank. After exposing the colonies to bright light for approximately $30 \mathrm{~min}$, larvae were released (Marshall \& Keough 2003). Specimens of the alga Chrysocystis fragilis were collected from Moore Reef $\left(16.53^{\circ} \mathrm{S}, 146.12^{\circ} \mathrm{E}\right)$ located east of Fitzroy Island in the GBR in January 2004. Monoclonal cultures of $C$. fragilis were established and maintained in enriched seawater (ES) medium (Provasoli 1964) at the North Queensland Algal Identification/Culturing Facility at James Cook University (culture no. NQAIF037).

Morphology, distribution and abundance of pedicellariae. The morphology and distribution of pedicellariae were investigated to determine if larvae of fouling organisms could potentially swim amongst and settle between pedicellariae without being in their physical range. Live specimens were placed individually in a round plastic container (160 $\mathrm{mm}$ in diameter), fully covered with sterile, filtered $(0.45 \mu \mathrm{m})$ seawater and observed with a Leica MZ 125 dissection microscope.

To determine the morphology and classify the pedicellariae of Acanthaster planci according to Jangoux \& Lambert (1988), pedicellariae without organic tissues were examined. Selected pedicellariae were removed from the surface and immersed in a $3.5 \%$ sodium hypochlorite $(\mathrm{NaOCl})$ solution until the organic tissue was cleared from the skeletal ossicles. The pedicellariae were then washed in distilled water, transferred to absolute ethanol and air-dried (Chia \& Amerongen 1975, Roberts \& Campbell 1988). Dried pedicellariae were gold-sputter coated and inspected using a JEOL JSM-5410LV scanning electron microscope with an accelerating voltage of $10 \mathrm{kV}$.

To determine if the total number of pedicellariae on the aboral surface area of Acanthaster planci is proportional to the size of the specimens, the total number of pedicellariae on the aboral surface of each collected specimen $(n=41)$ was counted. The aboral surface area of each specimen was estimated by measuring the radius of the disk $(r)$ as well as the length (measured from the interradial margin to the tip of an arm) and width of each arm at its base. Furthermore, the length of randomly selected pedicellariae $(n=10$ on each of 10 specimens) and the distance between randomly selected pedicellariae and their closest neighbouring pedicellaria ( $\mathrm{n}=10$ on each of 10 specimens) were 
measured using the image analysis program Leica IM50 Image Manager.

Pedicellariae may be either open or closed for an extended period of time. Open pedicellariae are potentially able to catch larvae or propagules of fouling organisms, whereas closed pedicellariae are not. Therefore, randomly selected pedicellariae $(n=100$ on each of 10 specimens) were observed after leaving the specimens in a container for 15 min without any disturbance. The percentage of open and closed pedicellariae of these specimens was then determined.

Tactile stimulation. The roles of pedicellariae in fouling control were investigated by observing their response to tactile stimulation with a hypodermic needle, silica and zirconium/silica beads, as well as to ecologically relevant fouling species, the bryzoan Bugula neritina and the chrysophyte alga Chrysocystis fragilis. Live specimens of Acanthaster planci were individually placed in a round plastic container $(160 \mathrm{~mm}$ in diameter) and fully covered with sterile, filtered $(0.45 \mu \mathrm{m})$ seawater. After leaving the specimens in the container for $15 \mathrm{~min}$ without disturbance, open pedicellariae were mechanically stimulated by touching either the inner, outer or basal sites of pedicellariae once with a small (Gauge 26 ) hypodermic needle $(\mathrm{n}=20$ pedicellariae for each site, randomly selected on each of 8 specimens, including $\mathrm{n}=10$ on central disk and $\mathrm{n}=10$ on arms). The closing responses of the pedicellariae to these stimuli were timed (i.e. the time from introduction of stimuli and closure of pedicellariae to the reopening of pedicellariae) using a Leica MZ 125 dissection microscope.

To simulate the effect of tactile stimulation by settling larvae and propagules of fouling organisms, 5 silica beads of 4 different mean sizes $( \pm \mathrm{SE}), 50.2 \pm 1.4$, $181.5 \pm 1.3,255.7 \pm 2.3$ and $510.7 \pm 3.8 \mu \mathrm{m}$, with a density of $2.5 \mathrm{~g} \mathrm{ml}^{-1}$ (Sigma-Aldrich) (Table 1), were dropped over each pedicellaria $(\mathrm{n}=20$ for each mean size, on the central disk of each of 8 specimens). The mass of these silica beads ranged between 0.2 and $174.4 \mu \mathrm{g}$ (Table 1), simulating the mass of a variety of

Table 1. Density, mean size $( \pm \mathrm{SE}$, diameter $)$ and mass per bead of silica and zirconium/silica beads used to stimulate pedicellariae on the central disk of Acanthaster planci

\begin{tabular}{|lccc|}
\hline $\begin{array}{l}\text { Type of } \\
\text { bead }\end{array}$ & $\begin{array}{c}\text { Density } \\
\left(\mathrm{g} \mathrm{ml}^{-1}\right)\end{array}$ & $\begin{array}{c}\text { Mean size } \\
(\mu \mathrm{m})\end{array}$ & $\begin{array}{c}\text { Mass per } \\
\text { bead }(\mu \mathrm{g})\end{array}$ \\
\hline Silica & 2.5 & $50.2 \pm 1.4$ & 0.2 \\
& & $181.5 \pm 1.3$ & 7.8 \\
& & $255.7 \pm 2.3$ & 21.9 \\
Zirconium/silica & \multirow{2}{*}{3.7} & $510.7 \pm 3.8$ & 174.4 \\
& & $191.2 \pm 1.9$ & 13.5 \\
& & $507.6 \pm 5.0$ & 253.4 \\
\hline
\end{tabular}

fouling organisms, including those used in this study. The tip of a 0.32 or $0.65 \mathrm{~mm}$ needle on a $250 \mu \mathrm{l}$ gastight syringe was positioned within $1 \mathrm{~mm}$ above each pedicellaria, and the beads were released, dropping onto the pedicellaria. The closing responses of the pedicellariae to these tactile stimuli were observed and timed. Furthermore, to test whether the size or mass of the artificial beads was important in triggering a closing response of the pedicellariae, zirconium/silica beads of similar mean size but of higher density than the silica beads were used. Five zirconium/silica beads of 2 mean $( \pm$ SE) sizes, $191.2 \pm 1.9$ and $507.6 \pm 5.0 \mu \mathrm{m}$, with a density of $3.7 \mathrm{~g} \mathrm{ml}^{-1}$ (Daintree Scientific) (Table 1), were dropped over each pedicellaria $(n=20$ for each mean size, on the central disk of each of 8 specimens). Again, the closing responses of the pedicellariae to these tactile stimuli were observed and timed.

To determine if pedicellariae are able to catch larvae and propagules of fouling organisms, randomly selected pedicellariae were stimulated with 2 ecologically relevant fouling species, the bryozoan Bugula neritina and the chrysophyte alga Chrysocystis fragilis. The bryozoan B. neritina (Bryozoa: Gymnolaemata: Cheilostomatida: Bugulaidae) is a cosmopolitan fouling organism found throughout warmer waters, including tropical Australia. It also occurs in abundance in harbours on pier pilings, ship hulls and buoys (OECD 1965). In contrast to larvae of other fouling organisms, larvae of $B$. neritina are comparatively large, with a diameter of approximately $250 \mu \mathrm{m}$ and a wet weight of approximately $5 \mu \mathrm{g}$. Using a $150 \mathrm{~mm}$ Pasteur glass pipette, 5 larvae of $B$. neritina of 2 ages, 0 to $2 \mathrm{~h}$ and 6 to $8 \mathrm{~h}$ (approximately $250 \mu \mathrm{m}$ in diameter), were slowly released within $1 \mathrm{~mm}$ of a pedicellaria $(\mathrm{n}=$ 20 on the central disk of each of 6 specimens). These age ranges were chosen because the non-feeding larvae of this species become less discriminatory in their choice of settlement substrate with larval age and, as such, older larvae may settle more rapidly (Marshall \& Keough 2003, Gribben et al. 2006).

The benthic colonial chrysophyte alga Chrysocystis fragilis (Chrysophyta: Pelagophyceae) is also found in the central GBR, where it colonises a variety of substrata, especially algal turf on rocks and dead standing corals, in water depths to at least $20 \mathrm{~m}$ (Lobban et al. 1995, Schaffelke et al. 2004). Mucilage fragments containing single cells (8 to $14 \mu \mathrm{m}$ in diameter) of $C$. fragilis were dropped over the pedicellariae $(\mathrm{n}=20$ on the central disk of each of 6 specimens). Three fragment lengths, 150-200, 550-600 and 950-1000 $\mu \mathrm{m}$, with a wet weight of approximately 25, 94 and $163 \mu$ g, respectively, were used because fragmentation has been suggested to be an important means of dispersal for this species (Lobban et al. 1995). The interaction between 
pedicellariae and larvae or fragments was observed using a Leica MZ 125 dissection microscope. The number of pedicellariae that closed after tactile stimulation were counted and expressed as a percentage of the 20 pedicellariae of each specimen. The closing responses of the pedicellariae were also observed and timed. As a control for the effect of seawater movement alone on the closing responses of the pedicellariae, filtered seawater without beads, larvae or fragments was slowly released from the syringe or pipette onto the pedicellariae and the reaction of the pedicellariae was observed.

Statistical analyses. All statistical analyses were performed with SPSS version 12. A Pearson correlation analysis was used to determine a potential correlation between the total number of pedicellariae and the estimated aboral surface area of 41 specimens of Acanthaster planci. Closure times between inner, outer and basal sites of the pedicellariae were analysed with a 3-factor mixed-model ANOVA (factors: (1) position on specimen - arm or disk; (2) site on pedicellariaeinner, outer or basal; (3) specimens [blocked factor]8 specimens of A. planci), followed by Tukey's honestly significant difference (HSD) multiple comparison test (Quinn \& Keough 2002). The assumptions of homogeneity and normality of the data were tested with standardized residuals versus predicted values plots and Q-Q plots of residuals, respectively. Because assumptions of homogeneity and normality were not met, the data were log-transformed. To calculate the minimum size and mass of silica beads required to trigger a closing response from the pedicellariae, a linear regression analysis was conducted using the data on the 4 different silica bead sizes and their corresponding mean percentages of closed pedicellariae. A 1-factor ANOVA was used to determine significant differences between mean percentages of responding pedicellariae to Bugula neritina larvae of 2 different age ranges. Assumptions for this analysis were met.

\section{RESULTS}

\section{Macro-fouling organisms on Acanthaster planci}

All observed specimens of Acanthaster planci $(\mathrm{R}=$ $59.1 \pm 2.8 \mathrm{~mm}, \mathrm{r}=31.2 \pm 1.4 \mathrm{~mm} ; \mathrm{n}=41$ ) were free of any macro-fouling organisms on their surfaces. One specimen of the commensal shrimp Periclimenes soror Nobili (Crustacea: Decapoda: Pontoniinae) was observed on the aboral surface of 1 A. planci $(\mathrm{R}=52 \mathrm{~mm}$, $\mathrm{r}=28 \mathrm{~mm}$ ) collected from Mid Reef in May 2005, whereas 2 specimens of the same shrimp species were observed on the aboral surface of $2 A$. planci $(\mathrm{R}=$ $87 \mathrm{~mm}, \mathrm{r}=46 \mathrm{~mm} ; \mathrm{R}=64 \mathrm{~mm}, \mathrm{r}=33 \mathrm{~mm}$ ) collected from Bait Reef in February 2006.

\section{Morphology, distribution and abundance of pedicellariae}

Asteroid pedicellariae can be classified into one of the following 3 categories: elementary, alveolar and complex, depending on the articulation of the valves with the underlying skeletal plate (Jangoux \& Lambert 1988). Scanning electron microscopy of pedicellariae without organic tissues demonstrated that all specimens of Acanthaster planci had only one type of pedicellariae: straight elementary. Each elementary pedicellaria consisted of 2 straight elongate valves (Fig. 1A) that were supported by a basal ossicle (Fig. 1B). When opening or closing, the 2 valves were able to move only in a linear plane with respect to each other, owing to the physical constraints imposed by the attachment of the valves to the basal ossicle.

The pedicellariae on the aboral surface of all observed specimens occurred individually amongst spines and papulae. The abundance of pedicellariae on the aboral surface was variable (Fig. 2). For example, 1 specimen of $37 \mathrm{~cm}^{2}$ had 783 pedicellariae (corresponding to 21 pedicellariae $\mathrm{cm}^{-2}$ ), whereas another with a similar surface area of $56 \mathrm{~cm}^{2}$ had 26 pedicellariae (corresponding to 2 pedicellariae $\mathrm{cm}^{-2}$ ). Despite this variation, the number of pedicellariae on the aboral surface generally increased with increasing surface area, because there was a weak but significant, positive correlation between the number of pedicellariae and the estimated aboral surface area of Acanthaster planci $(\mathrm{r}=0.587, \mathrm{p}<0.001)$. The length of the pedicellariae ranged between 0.2 and $1.5 \mathrm{~mm}$ with a mean $( \pm \mathrm{SE})$ of $0.7 \pm 0.1 \mathrm{~mm}$, and the distance between pedicellariae ranged between 0.7 and $5.8 \mathrm{~mm}$ with a mean $( \pm \mathrm{SE})$ of $2.6 \pm 0.3 \mathrm{~mm}$. Based on mean distance between the pedicellariae, mean density was estimated to be 14.7 pedicellariae $\mathrm{cm}^{-2}$. Because mean distance between pedicellariae was more than twice the mean length of pedicellariae, the pedicellariae were not able to physically cover and protect the entire aboral surface area from larvae or propagules of fouling organisms.

When specimens were left in a container for $15 \mathrm{~min}$ without disturbance, the majority of the pedicellariae $(79.5 \pm 3.2 \%)$ were open, i.e. potentially prepared for immediate closure and defence against larvae or propagules of fouling organisms.

\section{Tactile stimulation}

When open pedicellariae were touched at either inner, outer or basal sites using a hypodermic needle, and all pedicellariae responded and closed. The pedicellariae touched at inner sites closed for significantly 

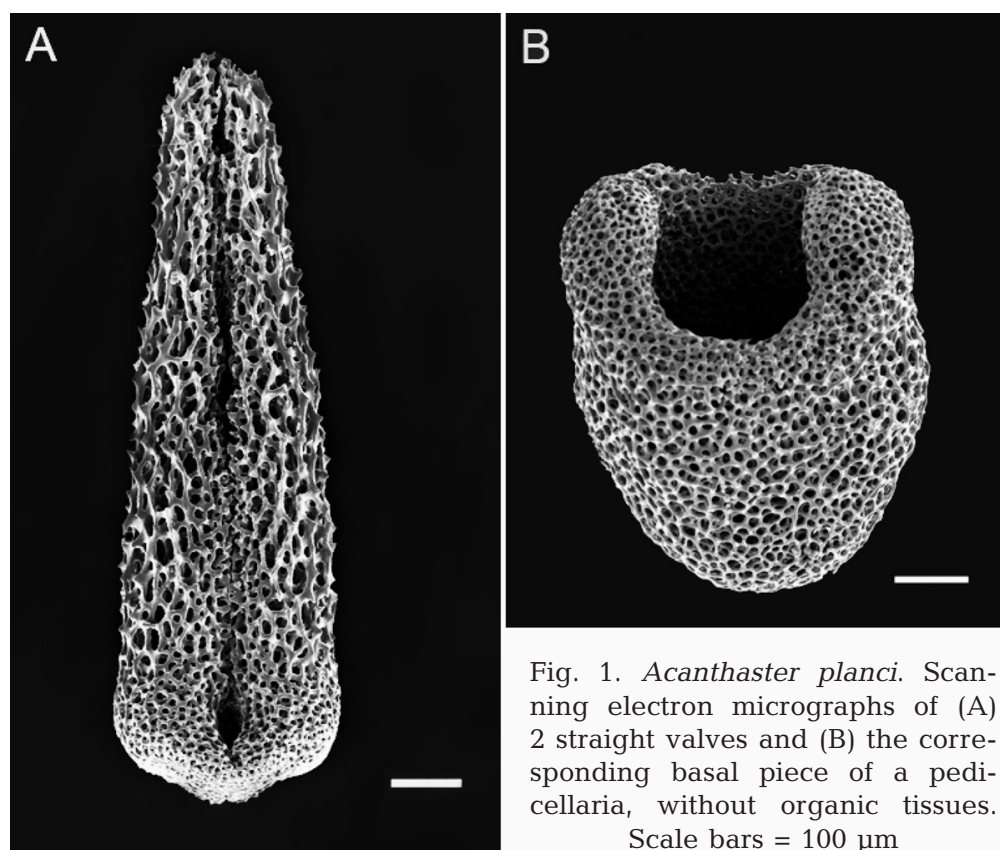

Fig. 1. Acanthaster planci. Scanning electron micrographs of (A) 2 straight valves and (B) the corresponding basal piece of a pedicellaria, without organic tissues. Scale bars $=100 \mu \mathrm{m}$ were used. The percentage of pedicellariae reacting to $191.2 \mu \mathrm{m}$ zirconium/silica beads was twice as high as the percentage of pedicellariae reacting to $181.5 \mu \mathrm{m}$ silica beads, i.e. $32.5 \pm 3.2 \%$ compared with $16.1 \pm 1.4 \%$. Similarly, the percentage of pedicellariae reacting to $507.6 \mu \mathrm{m}$ zirconium/silica beads reached the highest level of $100 \%$, whereas only $82.5 \pm 3.0 \%$ of the pedicellariae reacted to the $510.7 \mu \mathrm{m}$ silica beads (Fig. 4). These results demonstrate that the mass, not size, of the beads was the main driving factor behind the proportional increase in responding pedicellariae. From the linear regression $\left(\mathrm{r}^{2}=\right.$ $0.983, p=0.006$ ), the minimum size of silica beads required to trigger a response from the pedicellariae was calculated to be $>63.53 \mu \mathrm{m}$, which corresponds to a mass of $>0.34 \mu \mathrm{g}$.

The response of pedicellariae to larvae of the bryozoan Bugula neritina of varying ages was consistently low, with only 15.0

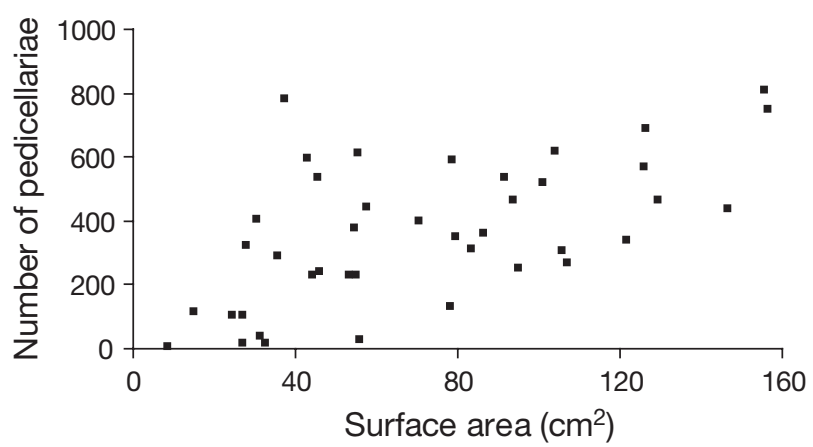

Fig. 2. Acanthaster planci. Correlation between the no. of pedicellariae and corresponding aboral surface area $\left(\mathrm{cm}^{2}\right)$ of each specimen $(n=41$; Pearson correlation analysis: $r=0.587$, $\mathrm{p}<0.001)$

longer than the pedicellariae touched at outer and basal sites ( $p=0.026$, Table 2). Pedicellariae touched at inner sites closed for $8.9 \pm 0.6 \mathrm{~s}$, whereas pedicellariae touched at outer and basal sites closed for $6.7 \pm 0.5$ and $7.9 \pm 0.7 \mathrm{~s}$ (SE), respectively (Fig. 3). While these differences are significant, the major outcome is that all pedicellariae closed for a period of time during which they were unavailable to react to another stimulus.

The percentage of pedicellariae that responded to tactile stimulation with silica beads $\left(2.5 \mathrm{~g} \mathrm{ml}^{-1}\right)$ of varying sizes increased with increasing size of the beads, i.e. from $0.4 \pm 0.4 \%$ (SE) for $50.2 \mu \mathrm{m}$ silica beads to $82.5 \pm 3.0 \%$ for $510.7 \mu \mathrm{m}$ silica beads (Fig. 4). However, the percentage of responding pedicellariae increased even further when zirconium/silica beads of similar size but higher density $\left(3.7 \mathrm{~g} \mathrm{ml}^{-1}\right)$ (Table 1) $\pm 4.1 \%$ (SE) and $10.8 \pm 2.0 \%$ of pedicellariae responding to 0 to $2 \mathrm{~h}$ and 6 to $8 \mathrm{~h}$ old larvae, respectively (Fig. 5A). There was no significant difference between these 2 responses $\left(F_{1,10}=0.839, \mathrm{p}=0.381\right)$. Those pedicellariae that responded to touch by the 0 to $2 \mathrm{~h}$ and 6 to $8 \mathrm{~h}$ old larvae closed quickly, with a mean closure time of $6.4 \pm 1.2 \mathrm{~s}(\mathrm{n}=18)$ and $4.3 \pm 1.0 \mathrm{~s}(\mathrm{n}=13)$, respectively (Fig. 5B). However, most of the pedicellariae were not quick enough to actually catch the $B$. neritina larvae. During the experiment, only 1 larva was caught by a pedicellaria, which subsequently held on to the larva for $5 \mathrm{~s}$, after which the valves of the pedicellaria opened again. The larva was released and was still able to swim off. The response to fragments of the fouling alga Chrysocystis fragilis of varying lengths (150 to 200, 550 to 600 and 950 to $1000 \mu \mathrm{m}$ ) dropped

Table 2. Acanthaster planci. Three-factor mixed-model ANOVA for log-transformed closure time of pedicellariae after they were touched with a hypodermic needle at inner, outer or basal sites (Position: arm or disk; Site: inner, outer or basal site of pedicellariae; Specimen: 8 specimens)

\begin{tabular}{|lrccc|}
\hline & df & MS & $F$ & $\mathrm{p}$ \\
\hline Position & 1 & 3.107 & 2.79 & 0.139 \\
Site & 2 & 3.388 & 4.80 & 0.026 \\
Specimen & 7 & 2.771 & 2.28 & 0.164 \\
Position $\times$ Site & 2 & 0.607 & 1.00 & 0.393 \\
Position $\times$ Specimen & 7 & 1.115 & 1.83 & 0.158 \\
Site $\times$ Specimen & 14 & 0.707 & 1.16 & 0.391 \\
Position $\times$ Site $\times$ Specimen & 14 & 0.608 & 1.14 & 0.323 \\
Error & 432 & 0.535 & & \\
\hline
\end{tabular}




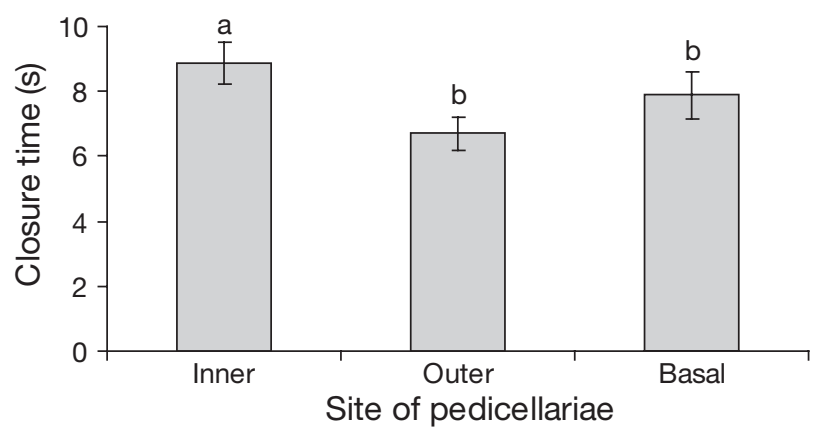

Fig. 3. Acanthaster planci. Mean closure time $( \pm \mathrm{SE})$ of pedicellariae when touched with a hypodermic needle at inner, outer or basal sites (3-factor mixed-model ANOVA followed by Tukey's HSD multiple comparison test; different letters indicate significant differences at $p<0.05$ for log-transformed data)

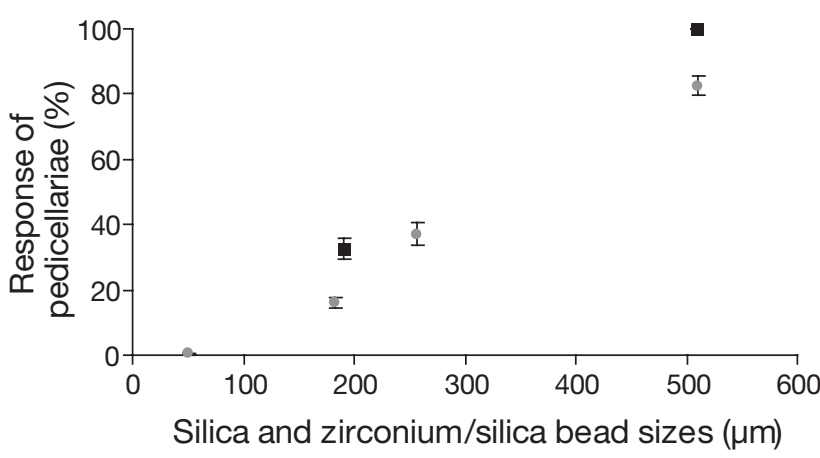

Fig. 4. Acanthaster planci. Mean percentage $( \pm \mathrm{SE})$ of responding pedicellariae to silica $(\bullet)$ and zirconium/silica ( $\bullet$ ) beads of different sizes

over the pedicellariae was even less than that of B. neritina, with no fragments triggering any closing response of the pedicellariae. Slowly releasing filtered seawater without any beads, larvae or fragments did not stimulate a closing response by any pedicellariae.

\section{DISCUSSION}

This study showed that the pedicellariae of Acanthaster planci were sparsely distributed, required a high force to trigger a closing response, slowly reopened and did not effectively respond to ecologically relevant fouling organisms. These results suggest that elementary pedicellariae of $A$. planci are not as effective in fouling control as previously implied (e.g. Nichols 1966, Ruppert \& Barnes 1994), if at all.

The elementary pedicellariae of the Acanthaster planci of this study were straight and were neither long nor dense enough to physically cover and protect the entire aboral surface area, providing a significant defence-free zone for potential settlement of fouling
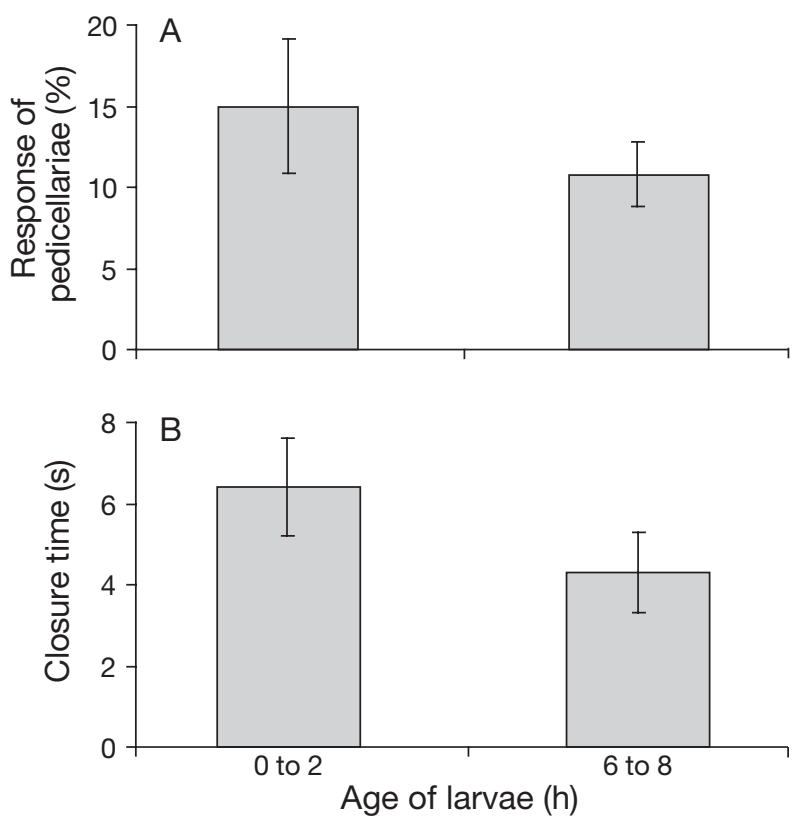

Fig. 5. Acanthaster planci. (A) Mean percentage $( \pm \mathrm{SE})$ of responding pedicellariae and (B) mean closure time $( \pm \mathrm{SE})$ of pedicellariae when touched by 0 to $2 \mathrm{~h}$ old $(\mathrm{n}=18)$ and 6 to $8 \mathrm{~h}$ old $(\mathrm{n}=13)$ Bugula neritina larvae

organisms. The mean length of the pedicellariae of this study was less than previously described. Pedicellariae of $A$. planci have been reported to be 2 to $3 \mathrm{~cm}$ long (Campbell 1971) and 1.5 to $2.5 \mathrm{~cm}$ long (Caso 1974), but in both studies it was unclear how many pedicellariae and specimens of $A$. planci were observed and how big the specimens were. The length of the pedicellariae may be a function of specimen size. However, mean length of pedicellariae in this study was similar to the length of straight complex pedicellariae of other asteroid species. The straight complex pedicellariae on the aboral surface of the sea star Marthasterias glacialis (Asteroidea: Forcipulatida: Asteriidae) were approximately 0.5 to $2.0 \mathrm{~mm}$ long, with a variable density of $>25$ pedicellariae $\mathrm{cm}^{-2}$ (Lambert et al. 1984). Similarly, the straight complex pedicellariae of the sea star Asterias rubens (Asteroidea: Forcipulatida: Asteriidae) were also small, reaching a length of 0.5 to $0.6 \mathrm{~mm}$; however, up to 3000 pedicellariae per specimen (of unspecified size) were recorded (Roberts \& Campbell 1988). In contrast to the pedicellariae of A. planci, the valves of the complex pedicellariae of M. glacialis and A. rubens are attached to the surface by a flexible stalk, which allows the valves to point in different directions (Lambert et al. 1984, Roberts \& Campbell 1988) and cover a greater surface area surrounding each pedicellaria. Therefore, alveolar and complex pedicellariae may have a more effective role in protecting the surface from fouling organisms. 
The responses of the pedicellariae of Acanthaster planci to the larvae of Bugula neritina were consistently low, and none of the pedicellariae responded to the fragments of Chrysocystis fragilis. Accordingly, there was also no response to any potential chemical stimulation associated with these organisms. Although comparatively large, the larvae of $B$. neritina weighed only $5 \mu \mathrm{g}$ and, when their swimming ability was taken into account, they were almost weightless in the water column. The larvae of $B$. neritina and fragments of $C$. fragilis clearly did not exert enough force onto the pedicellariae to trigger a response. Despite being free of any macro-fouling organisms, the straight elementary pedicellariae of $A$. planci do not seem to be the driving mechanism of this antifouling defence. Furthermore, asteroid pedicellariae only occur in some families of the orders Paxillosida, Notomyotida, Valvatida and Forcipulatida, and all families in the order Spinulosida lack pedicellariae (Jangoux \& Lambert 1988). Even at the species level, pedicellariae can be highly variable in numbers (Jangoux \& Lambert 1988), which was also demonstrated for $A$. planci in this study. Given that fouling pressure is universal and asteroid pedicellariae are variable in numbers or even lacking in numerous species, they may not have evolved for a protective role against fouling organisms. Alternative mechanisms, including physical and chemical (Bryan et al. 1996) antifouling defences, may contribute to the lack of fouling on A. planci and other species. The commensal shrimp Periclimenes soror may also play a role in keeping the surface of $A$. planci free of fouling, but there are virtually no records on potential food sources of this species.

Previous studies demonstrated that asteroid pedicellariae have functions in capturing particles and mobile prey (Chia \& Amerongen 1975) and deterring predators and competing sea stars (van Veldhuizen \& Oakes 1981). However, these functions may not apply to the straight elementary pedicellariae of Acanthaster planci. Specimens of $A$. planci feed mainly on staghorn and plate corals, rather than mobile prey, and also possess venomous spines to deter potential predators (Moran 1988). Nevertheless, the pedicellariae of A. planci may still have a limited protective role against small predators. Several species have been observed to feed on juvenile and adult A. planci, including the giant triton shell Charonia tritonis, the white-spotted pufferfish Arothron hispidus, 2 species of triggerfish Balistoides viridescens and Pseudobalistes flavimarginatus, 2 species of shrimp Hymenocera picta and Neaxius glyptocerus and the fire worm Pherecardia striata (reviewed by Moran 1986). Some predators may be smaller than A. planci and be able to move between the venomous spines without being affected by them. These predators are likely to exert a higher force onto the pedicellariae than the larvae or propagules of fouling organisms, and the resulting snapping action of the pedicellariae may deter them.

In conclusion, the theory that pedicellariae defend against the settlement of fouling organism does not hold for all asteroid species and needs to be reconsidered. Future research will need to examine the diverse range of species with pedicellariae of many types, especially both alveolar and complex pedicellariae, to determine if there is in fact any antifouling role for asteroid pedicellariae.

Acknowledgements. We thank the crown-of-thorns starfish control team (Association of Marine Park Tourism Operators), especially C. Zytkow for collecting specimens, S. Hudson for advice on fouling algal species and N. Paul for advice on statistical analyses. Financial support was provided by the Australian Defence Science and Technology Organisation: Biomimetic Fouling Control Program. J.G. was further supported by a James Cook University Postgraduate Research Scholarship and a CRC Reef augmentative grant.

\section{LITERATURE CITED}

Blake DB (1979) The affinities and origins of the crown-ofthorns sea star Acanthaster Gervais. J Nat Hist 13: 303-314

Bryan PJ, Rittschof D, McClintock JB (1996) Bioactivity of echinoderm ethanolic body-wall extracts: assessment of marine bacterial attachment and macroinvertebrate larval settlement. J Exp Mar Biol Ecol 196:79-96

Campbell AC (1971) Studies on some effector organs in echinoderms. PhD dissertation, University of Oxford

Campbell AC (1973) Observations on the activity of echinoid pedicellariae. I. Stem responses and their significance. Mar Behav Physiol 2:33-61

Campbell AC (1974) Observations on the activity of echinoid pedicellariae: II. Jaw responses of tridentate and ophiocephalous pedicellariae. Mar Behav Physiol 3:17-34

Campbell AC, Rainbow PS (1977) The role of pedicellariae in preventing barnacle settlement on the sea-urchin test. Mar Behav Physiol 4:253-260

Caso ME (1974) Morfologia externa de Acanthaster planci (Linnaeus). J Mar Biol Assoc India 16:83-93

Chia FS, Amerongen H (1975) On the prey-catching pedicellariae of a starfish, Stylasterias forreri (de Loriol). Can J Zool 53:748-755

Dearborn JH, Edwards KC, Fratt DB (1991) Diet, feeding behaviour, and surface morphology of the multi-armed Antarctic sea star Labidiaster annulatus (Echinodermata: Asteroidea). Mar Ecol Prog Ser 77:65-84

Emson RH, Young CM (1994) Feeding mechanism of the brisingid starfish Novodinia antillensis. Mar Biol 118: 433-442

Gribben PE, Marshall DJ, Steinberg PD (2006) Less inhibited with age? Larval age modifies responses to natural settlement inhibitors. Biofouling 22:101-106

Hendler G, Franz DR (1982) The biology of a brooding seastar, Leptasterias tenera, in Block Island Sound. Biol Bull (Woods Hole) 162:2273-2289

Jangoux M, Lambert A (1988) Comparative anatomy and classification of asteroid pedicellariae. In: Burke RD, Mladenov PV, Lambert P, Parsley RL (eds) Echinoderm Biology. Balkema, Rotterdam, p 719-723 
Jensen M (1966) The response of two sea-urchins to the seastar Marthasterias glacialis (L.) and other stimuli. Ophelia 3:209-219

Lambert A, De Vos L, Jangoux M (1984) Functional morphology of the pedicellariae of the asteroid Marthasterias glacialis (Echinodermata). Zoomorphology 104:122-130

Lauerman LML (1998) Diet and feeding behaviour of the deepwater sea star Rathbunaster californicus (Fisher) in the Monterey Submarine Canyon. Bull Mar Sci 63:523-530

Lobban CS, Honda D, Chihara M, Schefter M (1995) Chrysocystis fragilis gen. nov., sp. nov. (Chrysophyceae, Sarcinochrysidales), with notes on other macroscopic Chrysophytes (Golden algae) on Guam reefs. Micronesica 28:91-102

Lubchenco Menge J, Menge BA (1974) Role of resource allocation, aggression and spatial heterogeneity in coexistence of two competing intertidal starfish. Ecol Monogr 44: 189-209

Marshall DJ, Keough MJ (2003) Variation in the dispersal potential of non-feeding invertebrate larvae: the desperate larva hypothesis and larval size. Mar Ecol Prog Ser 255:145-153

Moran P (1986) The Acanthaster phenomenon. Oceanogr Mar Biol Annu Rev 24:379-480

Moran P (1988) Crown-of-thorns starfish: questions and answers. Australian Institute of Marine Science, Townsville

Nichols D (1966) Echinoderms. Hutchinson, London

Editorial responsibility: Howard Browman (Associate Editorin-Chief), Storebø, Norway
OECD (Organisation for Economic Co-operation and Development) (1965) Catalogue of main marine fouling organisms, Vol 2: Polyzoa. OECD Publications, Paris

Provasoli L (1964) Growing marine seaweeds. In: Davy de Virville AD, Feldmann J (eds) Proc 4th Int Seaweed Symp. Pergamon Press, New York, p 9-17

Quinn GP, Keough MJ (2002) Experimental design and data analysis for biologists. Cambridge University Press, Cambridge

Roberts MP, Campbell AC (1988) Functional anatomy of pedicellariae from Asterias rubens L. In: Burke RD, Mladenov PV, Lambert P, Parsley RL (eds) Echinoderm Biology. Balkema, Rotterdam, p 725-733

Robilliard GA (1971) Feeding behaviour and prey capture in an asteroid Stylasterias forreri. Syesis 4:191-195

Rowe FEW, Gates J (1995) Echinodermata. In: Wells A (ed) Zoological catalogue of Australia, Vol 33. CSIRO Publishing, Melbourne

Ruppert EE, Barnes RD (1994) Invertebrate zoology. Saunders College Publishing, Fort Worth, TX

Schaffelke B, Heimann K, Marshall PA, Ayling AM (2004) Blooms of Chrysocystis fragilis on the Great Barrier Reef. Coral Reefs 23:514

van Veldhuizen HD, Oakes VJ (1981) Behavioural responses of 7 species of asteroids to the asteroid predator Solaster dawsoni. Oecologia 48:214-220

Submitted: September 21, 2006; Accepted: December 21, 2006 Proofs received from author(s): May 28, 2007 